\title{
CT a művészetben
}

\author{
GYENES ZSOLT \\ Kaposvári Egyetem Rippl-Rónai Művészeti Kar Vizuális Intézet, H-7400 Kaposvár, Bajcsy-Zsilinszky Endre u. 10., \\ e-mail: dyenes@gmail.com
}

\begin{abstract}
GYENES, ZS.: CT in Art.
Abstract: Experimental artists are consciously looking for possibilities to make the program fail. So they play against the apparatus. Tomography is a process of imaging by sections, done through the use of any kind of penetrating wave. The normal use for Computer Topography is in medical imaging of the human body as object. The artist makes "improper use" of this system through placing different objects in the tomograph. The photographic images produced can be then animated, creating unexpected results in the form of abstract moving images. Metal causes disturbances to the magnetic field. It is considered to be a failure in CT-technology. At the same time, the aesthetic aspect of such disturbances prove interesting to the artist. She/He does not attempt to eliminate the disturbance, but on the contrary strengthen it. Stepping artefacts are inherent in this process. It can be a unique voyage; peeping into the inner workings of different technical instruments/apparatuses in an aesthetic and informative way. The CT scans of the author were taken at the Health Center of Kaposvar University in Hungary.
\end{abstract}

Keywords: Computed Tomography, Penetrative seeing, X-ray, Artefacts, CT-animation, Transparency, Abstraction, Media-art

A huszadik század második felétől felerősödött a mediális szemlélet a művészetben. A közvetlen alapok a klasszikus avantgárd idejére vezetnek vissza, mégis az elektronikus hang és kép, az audio-videó elterjedésével indul el valójában az a folyamat, mely a művészetben számtalan új, a techno-médiumokhoz köthető megoldást hoz. Ha még távolodunk az időben, akkor közel 180 évet is ugorhatunk; így a fényképezés, majd fél évszázaddal később a film és a röntgen technikájának újszerü lehetőségeit tárhatjuk fel. Ezek mind fontos előzményeknek számítanak tárgyunk szempontjából is. Érdekes adalék, hogy a röntgen pontosan egyidős a mozi/film születésével (1895). Ebben a dolgozatban ez utóbbi, illetve annak újabb formátumai érdekelnek minket leginkább. Azt is lényeges kiemelnünk, hogy az új technikák (tehát például a fotó, a film, a röntgen, a xerox, a videó és a számítógépes környezet) eredetileg nem a művészek „kedvéért” születtek meg. Mögöttük sokkal prózaibb okok állnak, amelyek kivétel nélkül a gazdasághoz, az üzlethez köthetök. Az is minden esetben megfigyelhető, hogy a megjelenő újabb médiumokat a művészek, jóformán születésük, illetve elérhetöségük pillanatától kezdve használni kezdték, kísérleteztek velük. Az experimentális attitüd hangsúlyozása azért is fontos, mert a kreatív alkotók nem használhatták, használhatják hasonló módon, - mint a marketing célokat első helyre helyező „kommunikátorok”, üzlet- emberek - ezeket az eszközöket, mert az eredmény olyan formán nem lehet/ett müvészeti produktum. Az „iroda” és a „müterem” másról szól, holott legtöbbször ugyanazt az apparátust, hardvert és olykor szoftvert használja mindkettő célja elérése érdekében.

Napjainkban jóformán minden múvészeti területen a techno-médiumok alapvető alkalmazásával találkozunk. A hagyományos kifejezési formákat, mint például a festészetet is formálják az új eszközök, megoldások. Példának okáért az újabb, gyakori megjelenésekre sorolhatjuk fel a következőket: animációkban, hang-textúrák kapcsán, elektrográfiákkal, interaktív és virtuális világok megalkotásával kommunikál, építkezik nagyon sok esetben a jelenkor múvészete. A kor nyelvén beszél a korhoz; hogy újabb generációkat érjen el.

Az eddig leírtakból következik tehát, hogy a (kísérleti) művésznek tudatosan a médium, a program/apparátus ellen kell dolgoznia. ${ }^{1}$ Ami müvészi (art/ificial), ami ember alkotta, az telítve van hibákkal is. A hibák önmagukban a másképpen való használatból eredeztethetőek. Tehát a kreativitás „hibás döntések sorozata”. Természetesen különféle perspektívák léteznek, melyek eltérő irányúak; így a fogalmak is előjelet válthatnak. Hibás metódusnak nevezhető, az előbbiek alapján például a loop-ok, ugrásaikkal együtt, az elektronikusan torzított kép és hang; mindezeket áthatva a teljesen eltérő, szokatlan szoftverhasználat. ${ }^{2}$

Mint már utaltunk rá, a klasszikus avantgárd időszakában sok olyan eljárás, gondolat születik meg, ami napjaink müvészetében is lényeges, meghatározó fontosságú. Moholy-Nagy László már az 1920-as évek közepén ír az átható látás fontosságáról, progresszív jellegéről. Kiemeli a röntgen szerepét a művészetben. A fotográfiai látás nyolc különböző változata között külön foglalkozik a röntgennel, a radiográfiával. Mellette olyan modern, korszerü fogalmak mentén rendszerez, mint az absztrakt-, egzakt-, gyors-, lassú-, intenzív-, szimultán- és torzított látás kategóriái. ${ }^{3}$ Mint új, fontos lehetőségként szól arról, hogy behatolhatunk és rögzíthetjük a tárgyak belsejét; olyan világ tárul fel, melyhez addig nem kerülhettünk közel. Moholy-Nagy követője, a szintén magyar

1 Vö. Vilém Flusser: A fotográfia (egy) filozófiája című müben írottakkal.

2 A számítógépes környezetben igazából a hardver mindenhol ugyanaz, a lényeg a szoftver-használatban rejlik és itt válhat teljesen szét, sőt ellentétként jelenhet meg az, amit az irodában tapasztalhatunk és azt, amit a müteremben... (Vö. Lev Manovich gondolataival)

3 L. Moholy-Nagy: Malerei, Photographie, Film, Munich, 1925; Vision in Motion, Paul Theobald, Chicago, 1947, 206-208 pp. 
származású Kepes György továbbmegy az úton. Az átható látást a transzparencia gyűjtőneve alatt értelmezi és egyféle optikai sürüségről ír híres müveiben. ${ }^{4}$

Az orvosi képdiagnosztikában, a legismertebb képalkotó eszközök a CT és az MRI. Ezek egy kétdimenziós felületre vetítve képezik le a háromdimenziós emberi testet. Számítógép segítségével rekonstruálható a térbeli testforma. ${ }^{5}$

A komputeres tomográfia (CT, Computed Tomography) röntgensugárzás segítségével gyűjt adatokat, majd sűrű metszeti képeket (rétegfelvételeket) alkot azokból (1-2. ábra). Az emberi test vizsgálatának másik ismert, elterjedt eszköze a mágneses rezonancián alapuló képalkotás (MRI, Magnetic Resonance Imaging). Ez is tomográfiás eljárás, tehát szeletképeket produkál, viszont a testben levő víz és a rádiófrekvenciák, illetve a mágneses tér egymásra hatásának észlelhető elváltozásain alapul. Ennek a technikának egyébként nagy előnye, hogy nem használ röntgenbesugárzást. A mágneses mezőnek és a rádióhullámoknak nincsen bizonyíthatóan a szervezetre káros hatása. ${ }^{6}$

Dolgozatunk tárgya a CT és MRI technika megjelenése a kortárs múvészetben. Körültekintve a kortárs „művészeti mezőn” nem sok példát találhatunk az ilyen megoldásokra. Viszont ami fellelhető, az izgalmasnak, újszerűnek bizonyul. Tudomány és múvészet találkozik, folytat párbeszédet egymással. Természetesen újabb, más lehetőségeket is tartogat magában ez a terület, mint amit itt számba veszünk. Nézzünk tehát néhány példát, mely látókörünkbe került!

Talán nemzetközi szinten a legismertebb „tomográfmúvész" a hong-kongi orvos, radiológus specialista, Kai-hung Fung. Praxisa melléktermékeként kezdett el a századunk első évtizede második felében művészi célzattal olyan képeket készíteni, melyek CT-szkennelésen alapultak. Egy sajátos módszert alakított ki, melyet rainbow technikának nevezett el. Állóképei kapcsán utazást tehetünk a test titkos belsejébe. A spektrum egymást követő színeire és a mélységélesség sajátos vizuális megjelenésére is épülő művein az egészen parányi részek is fókuszba kerülnek, egyedi értelmezést kapnak, különleges látványt nyújtanak. ${ }^{7}$ Organikus formák, mikro- és makrokozmosz „bio-romantikája” projektálódik a sík felületekre. Kai-hung Fung kiemeli a hiba építő jellegét is. Olyan artefact-okról beszél, melyek természetes velejárói a folyamatnak. A sajátos technikának, a szoftverhasználatnak részét képezik ezek. ${ }^{8}$ A hiba esztétikája, tehát meghatározó jelleggel alakítja a végső formát, megjelenést.

4 Gyorgy Kepes: Language of Vision, Paul Theobald and Company, Chicago, 1944/1969, 80. p.

5 https://www.merriam-webster.com/dictionary/computed $\% 20$ tomography\#medicalDictionary (2017. 01. 12), http://www.medicinenet.com/script/main/art.asp?articlekey=2878 (2017. 01. 12)

6 https://en.wikipedia.org/wiki/Magnetic_resonance_imaging (12. 01. 2017)

7 pl. Within One's Heart, CT kép, 2007-2009., http://www.slate.com/ blogs/brow-beat/2016/11/04/hbo_has_canceled_the_bill_simmons talk_program_any_given_wednesday.html (2016. 05. 11)

$8 \mathrm{http}: / / 3 \mathrm{~d}$ visa.cch.kcl.ac.uk/project37.html (2016. 05. 11), http://www. slate.com/blogs/browbeat/2016/11/04/hbo_has_canceled_the_bill_ simmons_talk_program_any_given_wednesday.html (2016. 05. 11)
Érdemes talán egy kicsit elidőzni ezeknél a „hibáknál”, ugyanis a CT müvészi felhasználásánál a dolgok lényegéhez tartoznak. A dolgozat elején már utaltunk arra, hogy a művészetben sok esetben ott kezd érdekessé válni egy technika, szoftver használata, ahol a hagyományos használat csődöt mond, illetve hibának, rossznak tekinti azt a formát, megoldást. Így van ez az orvosi képdiagnosztikában is. A különféle műtermékek (artefact-ok) a jelátvitelből és a kép rekonstrukciójából adódnak leginkább. ${ }^{9}$ Három fő csoportjuk közül, mint a jó, a rossz és a csúf, a két legutóbbi, de azon túl is a leges legutolsó érdekli jobban a művészt. A jelen szerző gyakorlatára építve írható, hogy a néhány „hiba-kategória” közül a ferromágneses mütermékek, tehát a fémek által kiváltott modifikációk, torzítások a legérdekesebbek. ${ }^{10}$ A tudatos fémhasználatot; - például vetítőgépek, televíziókészülékek, drótok behelyezését a tomográf gépbe, illetve azok vizsgálatát, szkennelését, együttesen a digitális elállításokkal, kísérletezéssel felettébb izgalmasnak és érdekesnek mondhatjuk esztétikai szempontból is (2. és 3 . ábra).

A kis kitérő után folytassuk tovább a kortárs müvészetből vett példákkal a megkezdett sort. Az MRI használaton alapulnak Angela Palmer „életvonalai” és Becky Stern hímzett „szeletei”. ${ }^{11}$ Palmer transzparens módon rétegzi az egyes tomográf képeket egymásra. A finom grafikus vonalak dinamikát kölcsönöznek a statikus emberi profilnak. Stern egy hagyományos médiumba, hímzett vászonba írja át a szigorúan tudományos látványt. Színhasználata és a motívum „selymes megjelenése" költészetet visz a képbe; humanizálja a kiindulás rideg megjelenését. Az interneten és a szakirodalomban kutatva nagyon kevés további figyelemre méltó példát lehet találni az orvosi képalkotó eljárások művészetben való felhasználására. Müvészet és tudomány fúziója ebben a vonatkozásban, tehát unikálisnak számít. Megemlíthető Silvia Casini: Scanning, Framing and Close-Up címmel, 2017-ben megjelent beszámoló tanulmánya, mely az MIT Leonardo címủ szaklapjában látott napvilágot. ${ }^{12} \mathrm{~A}$ kísérlet talán legérdekesebb momentuma a mozgókép és hang vizsgálatában teljesedik ki, ezzel még tovább szűkítve a példák sorát, de a másik oldalon pedig bővítve a médiumok tárházát, vizsgált témánkhoz igazodva. Ezen a helyen jegyezzük meg, hogy e sorok írója nyolc évvel ezelőtt kezdte el azon művészeti kutatásait a Kaposvári Egyetem Egészségügyi Centruma közreműködésével, segítségével, melyek a CT-technikából indultak ki. Ezek, az elejétől fogva a technika mozgóképi, animációs művészi célú megjelenítését helyezték a középpontba. Ezekről az írás végén olvashatunk majd egy rövid összefoglalást.

9 Berényi Ervin (2011): MR képalkotás. Online: http://www tankonyvtar.hu/hu/tartalom/tamop425/0019_1A_MR_kepalkotas/ ch08s04.html (2018. 01. 18.

10 Egy összefoglaló jellegü elektronikus kiadvány a szerző ez irányú munkáiból online (2017): http://vizualzene.hu/gyenes_tomo.pdf

11 http://visualoop.com/blog/5347/creating-art-with-mri (2016. 05. 11)

12 Silvia Casini: Scanning, Framing and Close-Up - Reimaging the Brain in 265 Looping Snapshots, Leonardo, Volume 50, Number 2, 2017, pp. 127-131. 


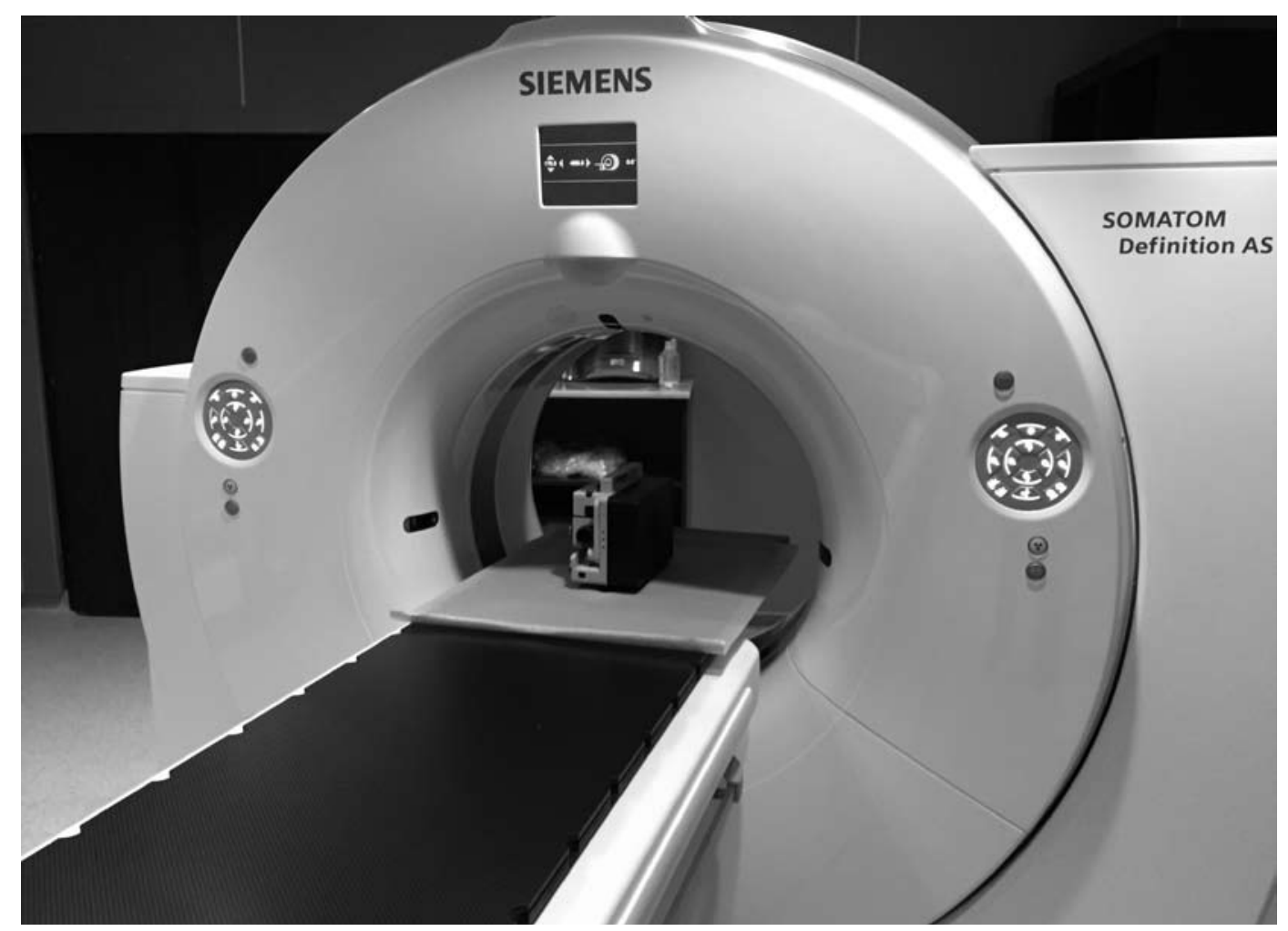

1. ábra. CT berendezés, melyben egy Szuper 8-as filmvetítő van elhelyezve. (A szerző fotója, 2017.)

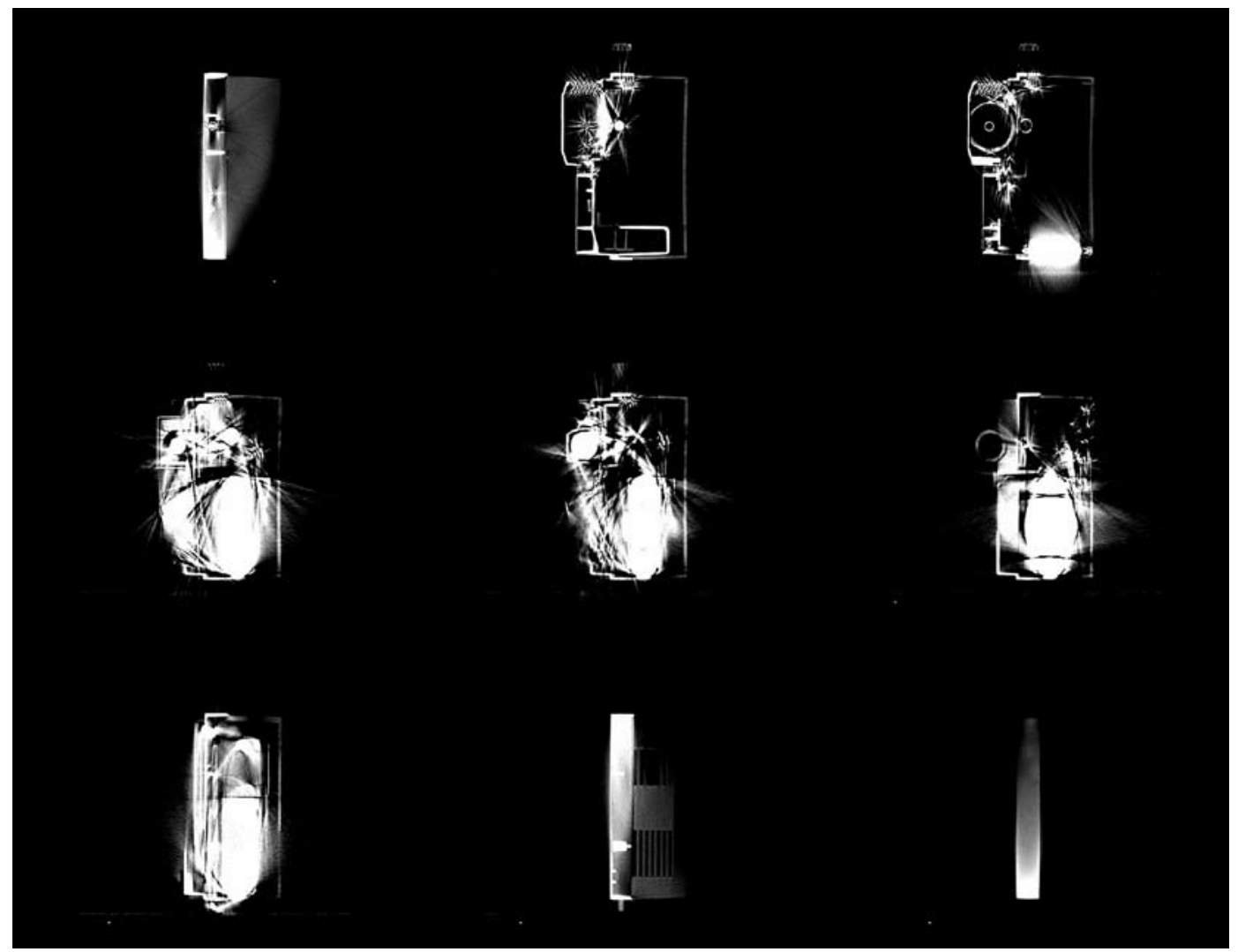

2. ábra. Válogatott CT rétegfelvételek egy filmvetítőröl, annak belső szerkezetéröl, a vizuális értékek módosításával. A szerző felvételei, 2017. A szkennelések a Kaposvári Egyetem Egészségügyi Centrumában készültek Dr. Donkó Tamás szakmai irányításával. 
A kevés fellelhető, orvosi képalkotó technikára alapozó művészeti példák közül figyelmet érdemel Horváth Erzsébet Corpus című, 2010-ben készült installációja (4. ábra). A művész vékony, átlátszó, egymás mögé fúzött fólialapok felhasználásával hozta létre munkáját. A testszeletek megfelelő vizuális megjelenítéséhez MRI szkenneléseket használt fel, melyek a Kaposvári Egyetem Egészségügyi Centruma támogatásával valósultak meg; kifejezetten ehhez a projekthez. A fel- vételek útmutatóul szolgáltak a rajzokhoz. A sötét-világos periodikus váltakozása, mely egy váltókapcsoló beiktatásával automatikusan vált irányíthatóvá; két különböző arcát mutatta a műnek. Mindkét esetben, az egyedi technika sajátos aurát jelenített meg, további fontos elemként. Világosban tejszerűen sejtelmessé vált, míg a sötétben, ahol a foszforeszkáló festék futurisztikus zöld árnyalata dominált, finom átmenetekben elhalkuló fényeket, tónusokat produkált ugyanaz

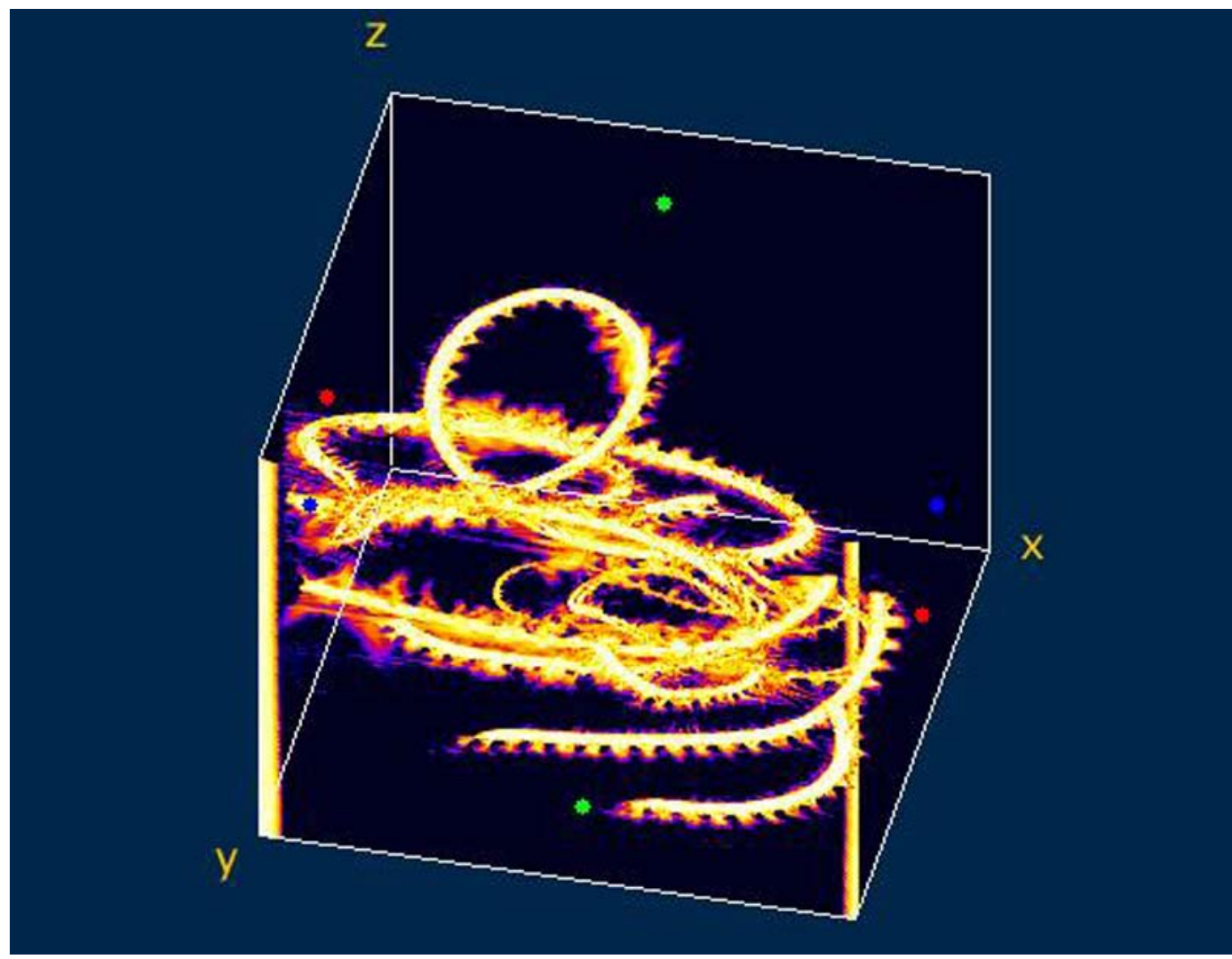

3. ábra. Egy beállított drótkompozíció a CT berendezésben (rekonstrukció). Az ábra mutatja a tudatosan előidézett modifikációkat is. (A szerző munkája. 2010.)
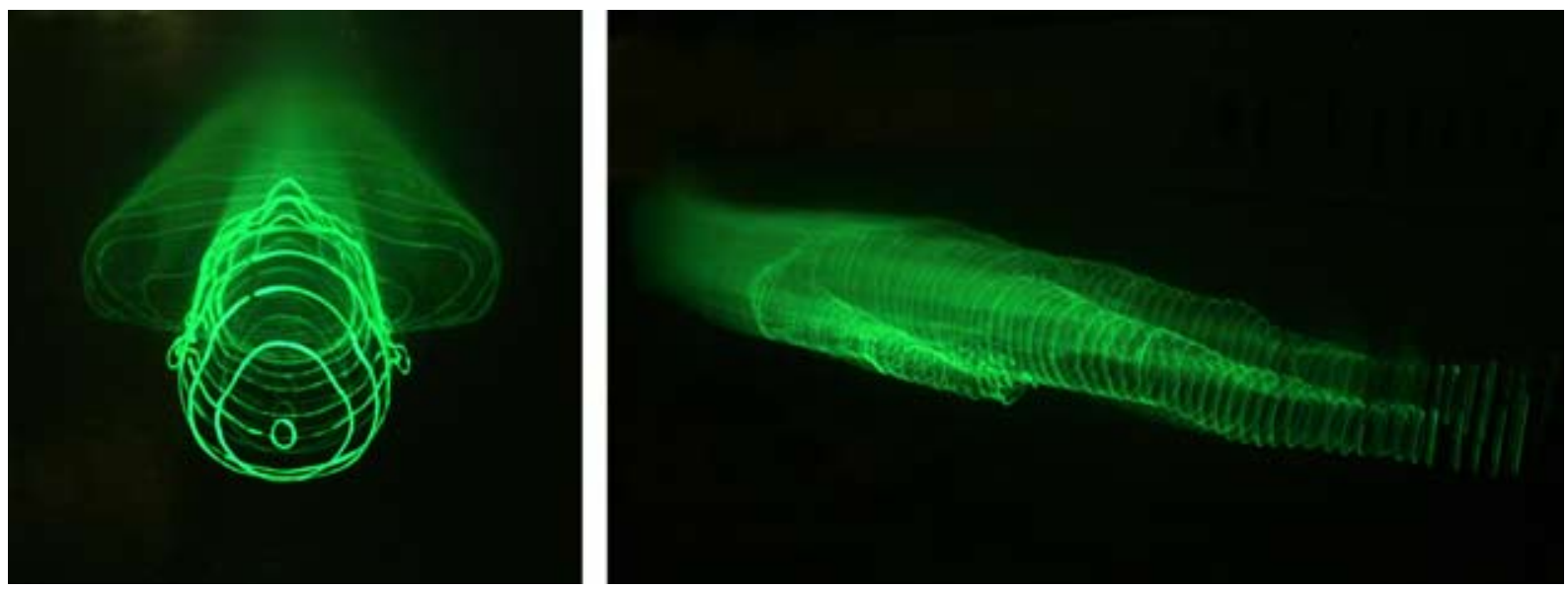

4. ábra. Horváth Erzsébet: Corpus, 2010. Installáció; transzparens fóliák, foszforeszkáló festék, fémrudak, reflektorok, időkapcsoló, 180x65x53 cm. A mü megjelenése sötétben. Két különböző nézet. A müvész szíves engedélyével. (A mühöz az MRI felvételek a Kaposvári Egyetem Egészségügyi Centrumában készültek) 
a körülbelül hetven különböző testszelet körvonala. A már említett fény-aura fogta össze térbeli egységgé, tömbszerü formává a különálló lapokat, egységeket. Az emberméretű forma lebegett a térben. ${ }^{13}$

$A z$ orvosi képalkotó technika használatára másik karakteres hazai példa Szigetvári Andrea, szintén 2010ben készült, CT című interaktív, élő elektronikus műve. Ebben az esetben a legújabb technika, az egyéni programozás, illetve számítógép-használat nagy hangsúlyt kapott. A mű kiindulási alapjául e sorok írójának másfél perc hosszú, 2394 képkockából álló CT-animációja szolgált. ${ }^{14}$ Egy beállított fém drót-kompozíció következetes „felszeletelése" alkotta az animáció képkockáit (I. még 3. ábra). A végeredmény, artefact-okkal vizuálisan modifikált absztrakt, mozgó, önmaguk tengelye körül forgó fénypontok lettek. Ez az absztrakció a konkrét (mozgóképes) művészet körébe tartozik inkább. ${ }^{15}$

„A hangzásfolyamatoknak és a zenének az a szerepe, hogy eszközként szolgáljanak az animáció jelentéseinek irányításához a pszichológiai térben. Mivel mindkét modalitás (a kép és a zene) absztrakt, így önmagukban gyenge, többértelmü jelentéssel bírnak. A kétféle információ találkozásából még mindig izgalmasan többértelmü, de a jelentéstérnek egy bizonyos szakaszára 'irányított' minőség keletkezik, melynek végső értelmezését a nézőnek/hallgatónak kell elvégezni. Ugyanannak a vizuális gesztusnak különböző hangzó leképzéseit interaktív zenei rendszer biztosítja, melyek paramétereit az előadó változtatja valós időben. A darab előadásához redukált multidimenzionális hangzástér készült, mely lehetővő teszi a különböző hangzásfolyamatok és zenei kifejezések közötti navigációt a videóból kinyert adatok segítségével." - írja a múvész. ${ }^{16}$

A dolgozat második, az előzőnél rövidebb egységében néhány olyan $\mathrm{CT}$, illetve MRI technikán alapuló művet ismertetünk, melyek az elmúlt, közel tíz évben készültek, szintén a Kaposvári Egyetem támogatásával. ${ }^{17}$ Személyes hangvételre váltva összegezzük példáink sorát, mivel azok ennek a dolgozat az írójának eredeti művei, kísérletei.

Mint már korábban érintettük, a fém megzavarja a mágneses mezőket; ami hibának számít az orvosi felhasználásban, diagnosztikában. Éppen ez érdekel leginkább esztétikai szempontból; nem hogy kiküszö-

13 Horváth Erzsébet: Kölcsönös áthatások - A transzparencia a kortárs képzőművészetben. DLA értekezés. Kézirat. Pécsi Tudományegyetem Művészeti Kar Doktori Iskola, Pécs, 2013, pp. 65-67.

14 Szigetvári Andrea (2012): CT - kép és hang kölcsönös átértelmezése interaktív zenei rendszer segítségével, Online: http:// vizualzene.hu/szigetvari_andrea.pdf (2018. 01. 22) Videó-részlet, online: https://www.youtube.com/watch?v=73o54m5s 2g (2018. 01. 22)

15 Az absztrakt- és konkrét müvészet fogalmainak tisztázásához segítséget nyújthat: Gyenes Zs. (2010): Az absztrakttól a konkrét fotóművészetig, prezentáció, Online: http://www.gyenes62.hu/abstr_hab_ready.pdf (2018. 01. 23)

16 Szigetvári Andrea (2012): CT - kép és hang kölcsönös átértelmezése interaktív zenei rendszer segítségével, Online: http:// vizualzene.hu/szigetvari_andrea.pdf (2018. 01. 22), pp. 2-4.

17 Ehhez összefoglaló jelleggel a következő, már említett elektronikus kiadvány nyújthat segítséget (I. 10. pont) : Gyenes Zs. (2017): Tomográfia / Tomography, online: http://vizualzene.hu/gyenes_tomo. pdf (2018. 01. 23) bölöm ezeket a mütermékeket, hanem felerősítem, kiemelem hatásukat, jellegüket. Sajátos mikroutazáson vehetünk részt; betekintünk esztétikai és információs értelembe is különféle eszközök, apparátusok belsejébe. Az animáció során időben, folyamatában haladunk végig; kerülhetünk egy láthatatlan, valójában megtapasztalhatatlan térbe. A mü saját, egyedi világa tárul fel... A munkák mediális értelemben önmagukra is reflektálnak, utalnak; például kivetítik a (film)vetítőt, ilyen módon feltárják önnön müködésüket is.

Személy szerint a CT-használatot részesítem előnybe az MRI-hez képest, ugyan is az előbbi erősebb vizuális modifikációkra nyújt lehetőséget már a szkennelés folyamatában is. A másik oldalon azt is megjegyezzük újból, hogy az MRI készítése viszont ártalmatlan az emberi szervezetre. CT-használatom kilencven százalékban tárgyakra épült. Első kísérleteim egy hordozható, régi televízió-készülék vizsgálatára irányult. Három dimenziós rekonstrukciókat is létrehoztam, megmozgattam, de ezeket túlságosan tudományos, kevésbé müvészi megjelenéseknek értékeltem. Valójában a készülékekben való „utazás” vált sokkal érdekesebbé, ahol a szkennelt szeletek dupla kockánként importálva, majd lejátszva alakultak mozgóképpé. A drótkompozíciók (vö. 3. ábra) egyedi, absztrakt, mozgó fénypontokat produkáltak. Ez a letisztultabb, tehát tiszta absztrakció bizonyult az egyik járható útnak (I. Szigetvári Andrea CT címủ müvének video-alapja). A már említett másik pólus; a részletekben is izgalmas készülékek (pl. szuper nyolcas vetítő vagy régi számítógép-egység) feltárását jelentette. Erre épült a legelső általam kiállított mű, mely CT-használatra épült, egy installáció Reggeli vizsgálat címmel. ${ }^{18}$

A loop az egyik legfontosabb „kiterjesztő lehetősége” az audio-vizuális müveknek. A gyökerek itt is az avantgárdhoz vezetnek. ${ }^{19} \mathrm{~A}$ vég nélküli ismétlések kimozdítják a nézőt is a megszokott mozi-, illetve televíziónézési szokásokból; a helyszín is áttevődik; leginkább képzőművészeti galériákba. A loop bizonyos szempontból hiba, nincsen eleje, se közepe, se vége, ráadásul a „hurok összeragasztásánál” ugrik egyet a kép és a hang. CT-alapú animációim sok esetben jelennek, jelentek meg folyamatosan ismételt lejátszással. Ilyen volt pl. a WWW című munka, 2010-ből vagy a legutóbbi nagyobb bemutatkozásom ezen a területen; a Tomography címú kiállítás Máltán, 2017-ben (5. ábra).

A mozgóképek melléktermékeiként olyan állóképek is kiragadhatók a sorból, melyek önállóan is megállják helyüket. A light-box egy sajátos technika, ahol a transzparens anyagra készült, vagy nyomtatott képek hátulról kapják egységes megvilágításukat; hasonlóan a gótikus katedrálisok üvegablakaihoz, vagy a monitorokhoz. CT-szeleteim átvilágításának a milyensége visszautal a röntgenképek tudományos vizsgálatához, szemlélésé-

18 Posztmédia kiállítás, SoBaBu Vizuális Művészeti Egyesület, K.B. Galéria, Kaposvári Egyetem (Rippl-Rónai) Művészeti Kar, 2009, Online: http://www.gyenes62.hu/sobabu/posztmedia.pdf (2018. 01. 24)

19 Megemlíthetjük ehhez kapcsolódóan Nam June Paik „Beatles Electroniques (1966-69)”, Malcolm Le Grice „Berlin Horse (1970)” és Brian Eno „14 Video Paintings (1981, 1984)” címü audio-video műveit. Kiegészítésképpen, online: http://www.ubu.com/film/ (2018. 01. 24) 


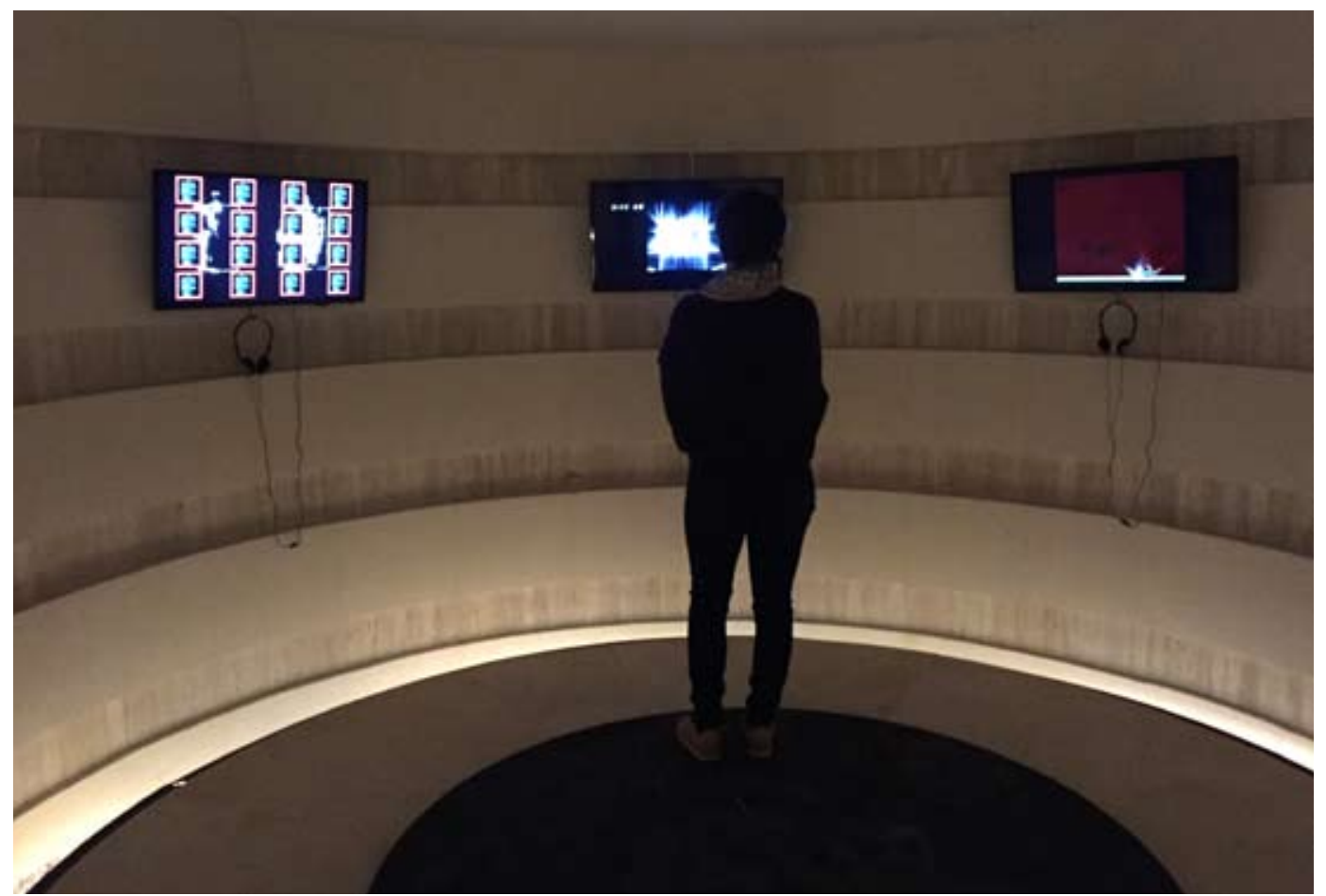

5. ábra. Gyenes Zs.: Tomography, videó-installáció, Valletta Internatioanl Visual Arts Festival, Málta, 2017. (A szerző felvétele)

hez is. Nyomdai síkfilmre készítettem el azt a világító dobozokban kiállított sorozatomat, melyek legutóbb Rómában kerültek kiállításra egy installáció részeként. ${ }^{20}$

A nagyrészt komputeres tomográf, kis százalékban MRI alapú munkáim, tehát leginkább mozgókép formájában „metarializálódnak”. A monitoron, vagy nagy méretben, tehát projektorral való vetítés más-más megjelenést ad az alkotásoknak. Előbbi intim szférájú, míg az utóbbi megoldásoknál a néző is belekerülhet a mü terébe; a vetítés látható fény-nyalábjai még tovább hangsúlyozzák a téri vonatkozásokat. Utóbbira egy szemléletes példa a Szinkrónia Opus 104 címü audio-video loop, mely néhány évvel ezelőtt a budapesti MAMÜ Galéria kiállítási térében a megnyitón játszó zenészekkel is „párbeszédbe lépett”.

$A z$ audio-video munkáknál a hang és mozgókép együtt építi fel sajátos tér-idejét, világát. Az ilyen művek leginkább kizökkentenek a megszokott, vagy annak vélt tér-idő folyamatainkból. Az időalapú kísérleti müveknél, melyek gyakran önnön müködésükre reflektálnak, izgalmas szegmens tehát a tér-időhöz kapcsolódó kérdések feltevése. A válasz leginkább elmarad. ${ }^{21}$

A Szinkrónia Opus 104 című münek a hang-környezete, hang-textúrája szintén egy hibán alapszik. Olyan szövegtöredékekből épül fel, melyet a Mac számítógép TextEdit Speech funkciója teremt meg. Ez a gépi funkció,

20 Szelet-képek, installáció, Római Magyar Akadémia, Olaszország, 90/10 címü kiállítás, 2017, online: http://www.gyenes62.hu/installations.html (2018. 01. 24)

21 Egy rövid filozófiai alapállású elmélkedés, töredék az idő megragadhatatlanságáról, online: http://vizualzene.hu/postcardrome.pdf (2018. 01. 25)
- akár mennyire is emberi, mert ténylegesen egy ember hangján szólal meg -, nem tud mit kezdeni a nem megszokott használattal. Ha értelmetlen, dadaista módon ismétlődő szövegtöredékeket gépelünk be számára, a szoftver el kezd dadogni, „,bezsongani”, kihagyni magánhangzókat és végeredményül hallatlanul izgalmas hangköltészet születhet. Erre a funkcióra építettem a nevezett és néhány más mü hangkörnyezetét. $A$ hang, mint már utaltunk rá, megváltoztatja a képek jelentését, de ugyanakkor a kép is generálja a hang-textúra jellegét.

Zárásként, még egyszer összefoglalom a CT és MRI technikán alapuló kortárs művek néhány érdekesnek ígérkező összetevőjét, jellemzőjét. A médium kimozdítása; a művészi praxis számára eltérő használat az eredeti funkcióktól jelentheti a megfelelő utat a kreatív alkalmazáshoz. A terület korántsem bejáratott. Új, nyitott lehetőségekkel számolhatunk még. Ilyen lehet például a mozgatott, mozgó objektumok szkennelése, vizsgálata; azokra épülő művek létrehozása. Másik terület lehet az egyre jobb felbontás megjelenésével a háromdimenziós alakzatok, vagy a nagy/obb méretű, illetve felbontású álló- és mozgóképek kivitelezése. ${ }^{22}$ A színes megjelenés is bejáratlan terület. Sajátos szinkrónia létrehozása valósulhat meg a szkennelést kísérő hang párhuzamos szerepeltetésével.

Tudomány és mủvészet egymást támogatva képes a világ szélesebb spektrumú megismerése felé lépéseket tenni; de már az is nagy szó lehet, ha jó kérdéseket képes feltenni, bevezetni.

22 Az átlagos CT technika $512 \times 512$ pixel felbontású, fekete-fehér szeletképeket produkál. 